\title{
Prediction of surface flow hydrology and sediment retention upslope of a vetiver buffer strip
}

\author{
Janet Hussein*, Bofu Yu, Hossein Ghadiri and Calvin Rose \\ Journal of Hydrology (2007) 338 p 261-272 \\ Australian Rivers Institute, The Griffith School of Environment, Griffith University, Nathan Campus, \\ 170 Kessels Rd, Nathan, 4111, Queensland, Australia \\ "Corresponding author.Email: j.hussein@griffith.edu.au
}

\begin{abstract}
Summary
Vegetated buffer strips are widely used to reduce fluxes of eroding soil and associated chemicals, from hillslopes into waterways. Sediment retention by buffers is time-dependent, with its effectiveness changing with the deposition process. Our research focuses on settling of sediment upslope of stiff grass buffers at three slopes, under subcritical flow conditions. A new model is developed which couples the hydraulics, sediment deposition and subsequent adjustment to topography in order to predict water and sediment profiles upslope of a buffer with time. Experiments to test the model were carried out in the Griffith University TiltingFlume Simulated Rainfall facility using subcritical flows at 1,3 and 5\% slopes. Water and sediment profiles were measured at different times as Vertisol sediment was introduced upslope of a vetiver grass strip. A region of increased flow depth (backwater) was produced upslope of the strip which increased in depth and decreased in length with increasing slope. Backwater height could be predicted from flow rates and thus could be used as an input for the model in the absence of experimental data. As slope increased, sediment was deposited closer to the grass strip, moving into the grass strip itself at 5\% slope. The grass strip was less effective in reducing outflow as slope increased and differences between slopes were significant. Model prediction of water and sediment profiles compared reasonably well with measured data, giving low root mean square errors and high coefficients of model efficiency approaching to 1 . Masses of deposited sediment were generally simulated within $20 \%$ of measured values. However, simulated particle size distributions of deposited sediment were less accurate.
\end{abstract}

\section{Keywords: Deposition; Backwater; Overland flow; Modelling; Vertisol; Grass;}

\section{Introduction}

The water quality in many river systems is deteriorating due to poor land management practices such as tree clearing, overgrazing, burning, cultivation and urban development. Riparian buffers are therefore frequently used in Australia and elsewhere, to reduce the influx of sediments and associated pollutants into these river systems (Newham et al., 2005), typically reducing sediment loads by between 40 to $95 \%$ (McKergow et al., 2004a). Grass buffer strips or hedges are also used as a cross-slope soil conservation technique to reduce sediment and pollutant loads on low slope agricultural lands. Buffers are often more cost effective to install and maintain than mechanical works. They have the advantage of being more aesthetically pleasing and they may provide habitat for wild-life. Many types of plants are used for buffers (Dabney, 2003), the choice being dictated by slope, soil type, climatic factors, potential sediment/pollutant loads and cost factors. Buffers work best when surface flow arrives as spatially diffuse sheet flow (Newham et al., 2005). When overland flow becomes concentrated, however, buffers may be overrun or breeched (McKergrow et al., 2004b) and at times can become a sediment source rather than a sediment sink (Dillaha and Inamdar, 1996)

Buffers generally reduce sediment and pollutant loads through a combination of deposition, infiltration and adhesion (Newham et al., 2005). Of particular interest in our study is the 
reduction of sediment delivery due to net deposition upslope of stiff grass buffer strips. The strip retards flow, causing a ponded area (backwater) immediately upslope, with a corresponding reduction in flow velocity. As sediment-laden flow reaches this ponded area, the coarser material with higher settling velocity is deposited whilst finer material moves into and often through the grass strip. The outflow from grass strips can thus contain soluble components and fine particles which comprise soil, organic matter and pollutants.

The physical processes involved in the reduction of particulate and dissolved material in, or before, buffer strips have been examined in a number of studies (Dabney et al., 1995; Deletic 2005; Dillaha et al., 1989; Ghadiri et al., 2001; Rose et al., 2003) and various models have been developed to describe some of these processes (Delectic, 2001; Flanagan and Nearing, 2000; Munoz-Carpena et al., 1999; Newham et al., 2005). Flanagan and Nearing (2000) validated the WEPP (Water Erosion Prediction Project) sediment sorting routine using a set of experimental data on sediment delivery through grass strips. While WEPP is able to predict the pattern of enriched sediment size distribution, the model over-predicts the medium size fractions and under-predicts the fine size fractions. The WEPP model only simulates the reduced sediment transport capacity in the hydraulically rough areas in the grass, but does not simulate the significant deposition in the ponded area upslope from the grass strip (Flanagan and Nearing, 2000).

The Kentucky model incorporated into a dynamic model by Munuz-Carpena et al. (1999) and the TRAVA model of Deletic $(2001,2005)$ has limitations in dealing with sediment of a wide variety of sizes and sediment concentrations. In the model of Newham et al. (2005), the settling process is not explicitly modelled in the backwater and the trapping capacity of the buffer is computed from the volume of the backwater. In addition, none of the current erosion models handles deposition in the zone of sediment accumulation upslope of the buffer, except when this is at a sufficiently early stage of net deposition, for its effect on flow to be negligible. Because of the settling process and flow adjustment in response to sedimentation, the buffer strip efficiency is time-dependent and changes as the sediment deposition builds up in the backwater region, adding to the complexity of the situation. Rose et al. (2003) assumed that the upslope movement of the backwater region is known, and its rate is constant. In addition, Rose et al. (2003) evaluated two alternative models for re-entrainment in the backwater region. As the change to water profile and flow characteristics in the backwater region during deposition is actually unknown, this paper tests a new modelling approach to couple the hydraulics, sediment deposition and subsequent adjustment to bed topography to simulate the build-up of sediments in the backwater zone and its effect on flow conditions.

The aim of our study is therefore to measure sequential water and sediment profiles before and after a grass buffer strip and to compare these to simulated data from the newly-developed GUSED (Griffith University Soil Erosion \& Deposition) model. Surface flow experiments were carried out in the Griffith University Tilting-flume Simulated Rainfall facility (GUTSR) at three different slopes, using a black clay soil. Previous flume experiments have been conducted with supercritical flows (Froude numbers $>1$ ) applied to different grass strips (Dabney et al.,1995; Dalton, 1997; Ghadiri et al., 2001; Metcalfe et al., 2003; Tollner,1977) using flow depths up to $600 \mathrm{~mm}$. However, a number of field and laboratory studies have shown that subcritical flow is common at low slopes and under low to medium intensity rainfall. Emmett (1978) concluded that Froude numbers $>0.2$ are not usually encountered on natural hillslopes and overland flows are mostly subcritical. Even on steep slopes up to $60 \%$ under high intensity rainfall, as examined by Presbitero et al. ( 2005) in the Philippines, Froude numbers were commonly $<1$ for sheet flow at the runoff plot scale (Rose, personal comm.) Our experiments therefore focused on subcritical flow, with flow depths less than $10 \mathrm{~mm}$

\section{Methods and materials}


The GUTSR consists of a $5.8 \mathrm{~m}$ long, $1 \mathrm{~m}$ wide flume, of adjustable slope (Ghadiri et al., 2001). Experiments were carried out in a $3.5 \mathrm{~m}$ by $0.3 \mathrm{~m}$ section constructed within the flume. A self-mulching black clay classified as a Vertisol (FAO, 1998) or Vertosol (Isbell, 1996) from the Darling Downs area $\left(27^{\circ} 54^{\prime} \mathrm{S} 152^{\circ} 34^{\prime} \mathrm{E}\right)$ was used as the inflow sediment for this study. Vertisols are prevalent world wide, occupying about 300 million ha, and are very prone to sediment loss through erosion (Freebairn and Wockner, 1986; Probert et al., 1987).

\subsection{Analysis of soil and inflow sediment}

Some properties of the Vertisol are provided in Table 1. Soil textural class was determined from standard particle size analysis data (13\% sand, 23\% silt and 64\% clay) (Australian Standards, 1995). Soil $\mathrm{pH}$ and electrical conductivity was measured at a 1:5 ratio using a TPS Conductivity Meter. Exchangeable cations were determined using the rapid ammonium acetate extraction method at $\mathrm{pH} 7$ and corrected for soluble salts using saturation extracts (Rayment and Higginson, 1992). Cation exchange capacity (effective CEC) was determined from exchangeable bases and exchangeable acidity using the $\mathrm{KCl}$ method (Rayment and Higginson, 1992).

Table 1

Analytical data for the Vertisol used in the experiments

\begin{tabular}{|c|c|}
\hline Property & Value \\
\hline Soil textural class & Clay \\
\hline $1: 5 \mathrm{pH}$ in $\mathrm{CaCl}_{2}$ & 7.3 \\
\hline Electrical conductivity of $1: 5$ suspension $(\mathrm{dS} / \mathrm{m})$ & 0.191 \\
\hline Cation Exchange Capacity $\left(\right.$ mmoles $\left._{+} / \mathrm{kg}\right)$ & 643 \\
\hline Exchangeable $\mathrm{Ca}\left(\right.$ mmoles $\left._{+} / \mathrm{kg}\right)$ & 126 \\
\hline Exchangeable $\mathrm{Mg}\left(\mathrm{mmoles}_{+} / \mathrm{kg}\right)$ & 512 \\
\hline Exchangeable $\mathrm{Na}\left(\right.$ mmoles $\left._{+} / \mathrm{kg}\right)$ & 3 \\
\hline Exchangeable $\mathrm{K}\left(\right.$ mmoles $\left._{+} / \mathrm{kg}\right)$ & 2 \\
\hline Exchangeable Sodium Percentage & 0.5 \\
\hline
\end{tabular}

To determine the aggregate/particle size distribution of the inflow sediment (Fig. 1) used in the GUTSR experiments (section 2.2), three samples $(\sim 500 \mathrm{ml})$ were collected from the dispenser in the flume and analysed by wet sieving and sedimentation. The sample volume was measured and the sample then fractionated through nest of sieves (mesh sizes 2.00, 1.00, 0.50, $0.25,0.106$ and $0.054 \mathrm{~mm})$. The sediment left on each sieve was gently oven dried at $50^{\circ} \mathrm{C}$ and then weighed (Ghadiri et al., 2001). Sediment passing through the bottom sieve $(<0.054 \mathrm{~mm})$ was collected and analysed by sedimentation in a 1 litre cylinder using the pipette technique. The total sediment weight was then summed over all the size fractions and divided by the volume of the inflow sample to give a sediment concentration corrected to a 1 litre basis $(\mathrm{g} / \mathrm{l})$. The mean weight diameter (MWD) of the inflow sediment $(0.225 \mathrm{~mm})$ was calculated according to Van Bavel (1950) as $M W D=\sum x i$ wi, where $x i$ is the mean diameter of each size fraction and $w i$ is the proportion of the total sample mass occurring in each size fraction.

The settling velocity characteristics of the inflow sediment are also shown in Fig. 1. The settling velocities were calculated from the wet sieving size class data employing the equation of Cheng (Cheng, 1997), using a aggregate/particle density of $1600 \mathrm{~kg} / \mathrm{m}^{3}$. Cheng's method is based on an explicit relationship between the particle Reynolds number and the particle drag coefficient, with a standard shape factor. The aggregate density was estimated from the sand fraction ( $>0.02 \mathrm{~mm}$ ) using an empirical relationship developed by Loch and Rosewell (1992). Examination of the size distribution in Fig. 1 shows that there is $<20 \%$ 'clay + silt ' sized particles $(<0.02 \mathrm{~mm})$ in the inflow sediment, despite the fact that the sediment has $87 \%$ of 
these particles when fully dispersed. This indicates that the inflow sediment was strongly aggregated.

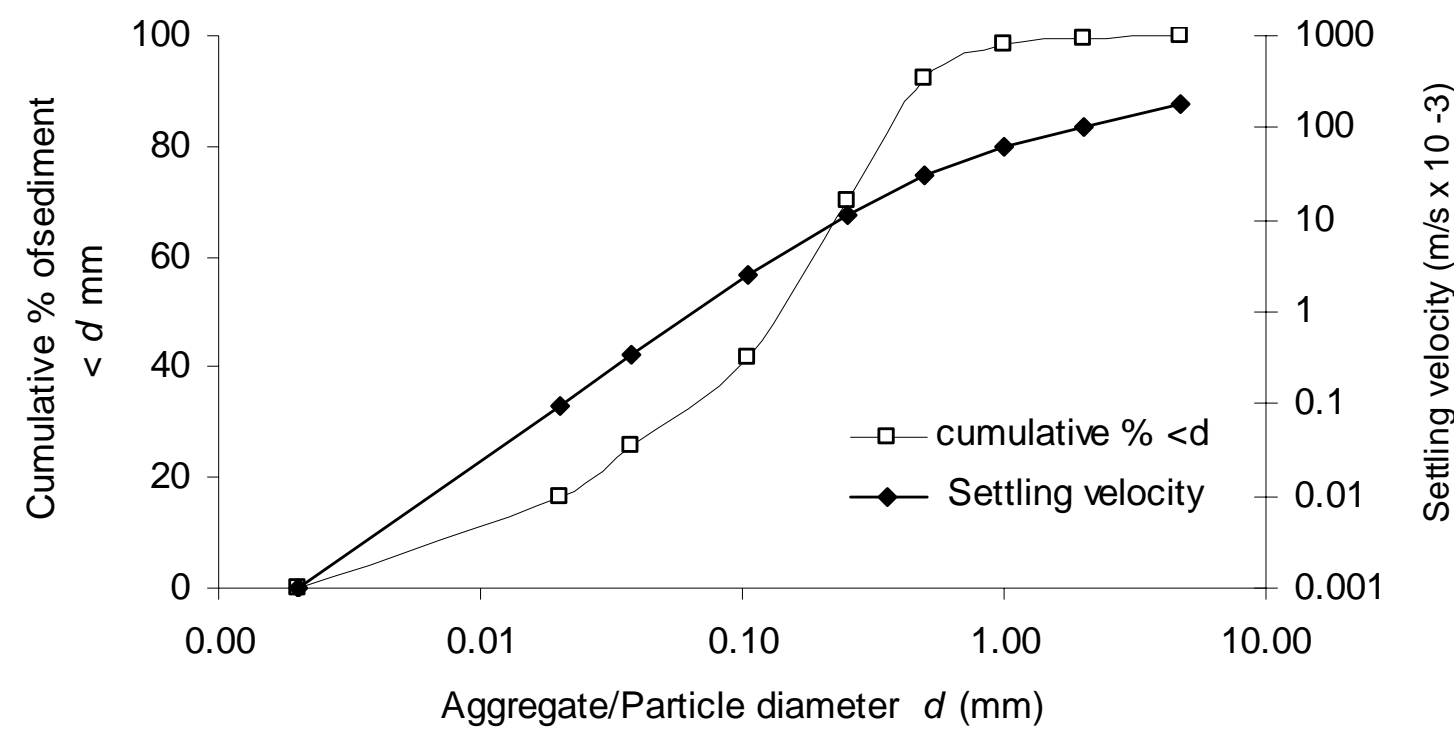

Fig.1. Settling velocity distribution for inflow sediment

\subsection{Flume experiments}

Vetiver grass (Vetiveria zizaniodes L., sterile cultivar Monto) was used for the buffer strip in our experiments as it is commonly employed for erosion control in Australia (Truong, 1999; McKergow et al., 2004a b) and elsewhere in the world. It has a tall, erect stature, a very strong rooting system and is tolerant of a wide range of moisture and soil conditions. Vetiver grass strips (often called hedges) are commonly planted as single rows, spaced at appropriately designed intervals to account for changes in slope. For the flume experiments, dense vetiver strips $(0.3 \mathrm{~m}$ wide) were grown in planting boxes. Prior to transferring a strip to the flume, the entire root system was dipped into a Plaster of Paris mixture to prevent sediment washoff from the root bed and to give firm anchorage to the plants, similar to that experienced by deeply rooted vetiver in the field. The completed strip was thus $0.3 \mathrm{~m}$ in width (to fit across the flume) and $0.3 \mathrm{~m}$ in length (along the flow path of the flume) with a stem density of $4300 \mathrm{stems} / \mathrm{m}^{2}$. Average stem/culm width was $9 \mathrm{~mm}$ at $30 \mathrm{~mm}$ height. The completed length was similar to that of a vetiver strip in arable fields after $\sim 1$ year of growth (Dalton, 1997). The block was inserted in the flume (Fig. 2) and a raised flume surface was constructed level with, and on either side of the vetiver strip, using boards. In order to simulate a rough soil surface, the faces of the boards were covered using a rough material. The Manning's coefficient of this material (0.04) was determined from previous measurements of slope, flow depth, flow rate and flume width in experiments without the buffer.

Three replicate experiments were conducted at each of 1, 3 and $5 \%$ slopes using unit flow rates of $0.33,0.67$ and $1.0 \times 10^{-3} \mathrm{~m}^{3} / \mathrm{m} . \mathrm{s}$ respectively, applied upslope of the vetiver strip (Fig. 2). This produced an average flow depth of $8.0 \pm 0.6 \mathrm{~mm}$ upslope of the backwater region. After stabilization of flow, the water surface elevations upslope and downstream of the vetiver were recorded using thin, rigid, PVC strips impregnated with water-soluble potassium permanganate dye, inserted into, and parallel to, the flow in the centre of the flume (Ghadiri et al., 2001). The water dissolved the dye leaving a sharp watermark. The strips were then dried and photocopied and the water depths digitised from the photocopies. Runoff rate was also measured by recording the volume (collected in a bucket) from the outflow (Fig. 2) in a unit 
time. The soil was then introduced as slurry into the surface flow through the dispenser. The inflow rate was reduced slightly to maintain at the total flow rate because of the introduction of sediment-laden flow. The loose slurry was prepared by wetting $180 \mathrm{~g}$ air-dry sieved soil $(<4.76$ $\mathrm{mm}$ ) in each of 20 buckets with 1 litre of water. This was done two hours prior to each run, followed by stirring, to ensure full saturation/swelling of the soil. The slurry was then added to the dispenser from the buckets, every minute over the 20 minute duration of the experiment. The sediment was continuously agitated in the dispenser with an electric mixer, to ensure an even distribution of sediment into the inflow.

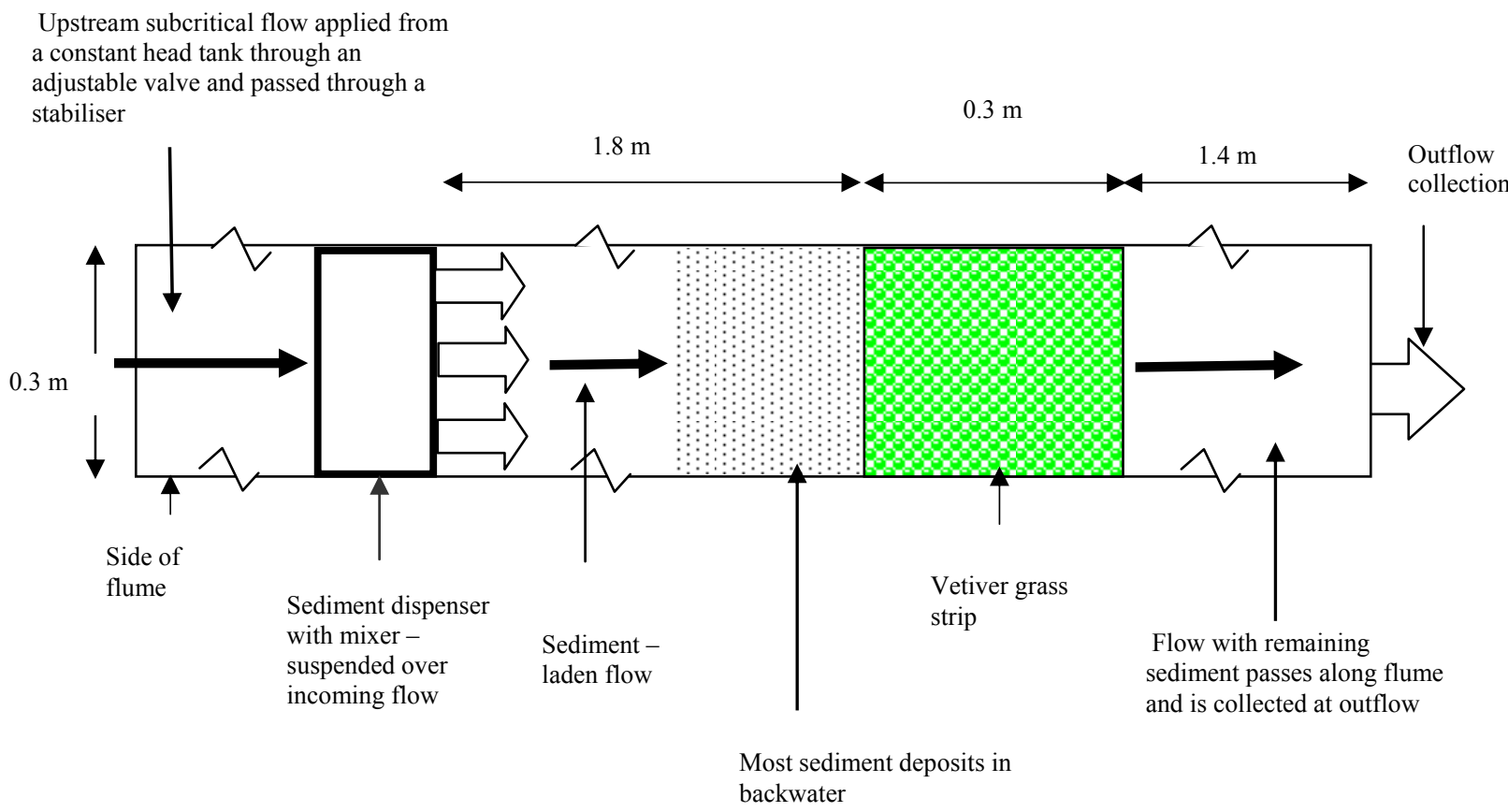

Fig.2. Overhead view of GUTSR flume showing experimental design

Outflow samples were collected in $600 \mathrm{ml}$ beakers at 2 minute intervals during each run, for measurement of sediment concentration. Larger outflow samples were collected in buckets at 4 minute intervals and analysed for aggregate/particle size distribution (as previous) and for outflow rate. The rate of vertical build-up of deposition upslope of the grass strip was estimated using small zinc tags $(20 \times 20 \times 1 \mathrm{~mm})$ introduced into the flow at different distances, and times. At the end of the sediment addition, the elevation of the new water surface was measured, using dyed PVC strips. After flow ceased, surface elevation of the sediment both across and along the flume was photographed and then measured using dyed PVC strips. The digitised data relating to flow/deposited sediment depths were recorded on charts. An example is illustrated in Fig. 3 for one of the 5\% slope replicates and is later discussed in section 3.1. Upslope distances from the start of the grass strip (at $0 \mathrm{~m}$ ) are presented as negative values. Flow depths were corrected relative to $0 \mathrm{~mm}$ elevation, at the start of the grass strip. Flow depths inside the buffer zone were not recorded, due to the thick foliage of the grass. Depths to the tags imbedded in the sediment were also recorded, and then samples of the sediment were taken from different distances upslope of the grass strip. The deposited sediment samples were analysed for particle size distribution by wet sieving and pipette analysis as previous. 
Four replicate cores were taken using thin aluminium samplers (48 $\mathrm{mm}$ diameter) in the deepest part of the deposited sediment for the 5\% slope replicates (commonly $2-3 \mathrm{~cm}$ in thickness) to determine wet (saturated) and dry bulk density. Sediment deposits were too thin to take representative cores for the 1 and $3 \%$ slopes.

Statistical t-tests (at the 5\% probability level) were used to test the hypothesis that there was no difference between the mean data values measured for the inflow sediment and the deposited sediment at the different slopes. The spread of data points for the groups of data were similar and the variances were assumed equal. To examine linear relationships between selected data, regression equations were fitted using Excel and the $F$ values were examined for level of significance. Examination of residuals showed no violation of linearity or normality assumptions.

\subsection{GUSED model and its input requirements}

To better understand the depositional processes upslope of buffer strips, a numerical model of soil erosion and deposition, known as GUSED, was used to simulate the accumulation of sediments upslope of buffer strips as a result of reduced stream power in the backwater region. GUSED fully implements the model developed by Rose et al. (2003) to describe the magnitude and extent of deposition and the size distribution of deposited sediments. In addition, GUSED simulates the evolution of the deposited layer by dynamically adjusting bed elevation and water profile, and velocity as a result of sediment accumulation. The output of GUSED includes water surface and bed profiles at different distances upstream of the buffer at the end of each time step, as well as the sediment concentrations in the flow for each size class, at the upstream end of the buffer. To do this, GUSED attempts to solve the following set of coupled ordinary differential equations:

$$
\begin{aligned}
& \frac{d y}{d x}=\frac{S_{o}-S_{f}}{1-F_{r}^{2}} \\
& q \frac{d c_{i}}{d x}=-v_{i} c_{i}+\frac{F \sigma \rho V S_{f}}{(\sigma-\rho)} \frac{v_{i} c_{i}}{\sum v_{i} c_{i}}, \quad i=1, \ldots n \\
& \frac{d z_{o}}{d t}=-\frac{q}{\sigma(1-\lambda)} \frac{d c}{d x}
\end{aligned}
$$

where $\mathrm{y}$ is the water depth $(\mathrm{m}) ; x$ is the distance in down slope direction $(\mathrm{m}) ; S_{f}$ is the frictional slope $(\mathrm{m} / \mathrm{m}) ; \quad S_{o}$ is the bed slope $(\mathrm{m} / \mathrm{m}) ; \quad F_{r}$ is the Froude number, $q$ is the unit discharge $\left(\mathrm{m}^{3} / \mathrm{m} . \mathrm{s}\right) ; c_{i}$ is the sediment concentration in size class $i\left(\mathrm{~kg} / \mathrm{m}^{3}\right) ; v_{i}$ is the fall velocity for size class $i(\mathrm{~m} / \mathrm{s}) ; F$ is the fraction of stream power available for entraining sediments; $\rho$ is the water density $\left(\mathrm{kg} / \mathrm{m}^{3}\right) ; \sigma$ is the wet density of sediments $\left(\mathrm{kg} / \mathrm{m}^{3}\right) ; V$ is the velocity of flow $(\mathrm{m} / \mathrm{s}) ; z_{\mathrm{o}}$ is the bed surface elevation $(\mathrm{m}), t$ is the time $(\mathrm{s}) ; c$ is the total sediment concentration $\left(\mathrm{kg} / \mathrm{m}^{3}\right)$; and $\lambda$ is the porosity $\left(\mathrm{m}^{3} / \mathrm{m}^{3}\right)$.

Equation (1.a) is the governing equation for steady gradually varied flow, namely the backwater equation (Chow, 1959). The first term on the right hand side of equation (1.b) is the sink term due to deposition; the second term due to re-entrainment of deposited sediments (Rose et al., 2003). The frictional slope in Equation (1.a) is evaluated using the Manning's equation:

$S_{f}=\frac{n^{2} q^{2}}{y^{10 / 3}}$

where $n$ is the Manning's roughness coefficient. 
Bed slope and total concentration are given by:

$$
\begin{aligned}
& S_{o}=\frac{d z_{o}}{d x} \\
& c=\Sigma c_{i}, \quad i=1, \ldots n
\end{aligned}
$$

The initial condition is that $z_{o}=$ known initial bed profile $\left(z_{0}\right.$ at $\left.\mathrm{t}=0\right)$, and $\mathrm{y}=\mathrm{y}_{\mathrm{o}}$ at $t=0$ and $x=$ 0 (the downstream end of the deposition zone), and the boundary condition is that at some distance well upslope of the backwater region, $q=q_{o}$, and $c=c_{o}$ for all $t$.

The coupled ordinary differential equations are solved for each time step. The Runge-Kutta method with adaptive step-size control was used. We implemented a routine using Cash-Karp parameters for the embedded Runge-Kutta method (Cash and Karp, 1990; Press et al., 1992). The bed profile was updated at the end of each time step. This in essence assumes a series of steady state solutions of flow and sediment transport and deposition.

The required input variables used to run the simulations for GUSED are summarised in the first column of Table 2. Additionally, the following input parameters were used: water density $(\rho)$ and wet density of sediment $(\sigma)$ of $1000 \mathrm{~kg} / \mathrm{m}^{3}$ and $1600 \mathrm{~kg} / \mathrm{m}^{3}$ respectively; Manning $n$ of 0.04; Fraction of stream power available for entrainment $(F)=0.1$; threshold stream power $(\Omega)=0.008 \mathrm{~kg} / \mathrm{m}^{3}$ and nine size classes for the sediment. The average settling velocity is $0.009664 \mathrm{~m} / \mathrm{s}$, and the velocity distribution is given Fig. 1 .

The spatial and temporal resolution for GUSED is set by the user, so is the spatial extent, and the duration of simulation. For this study, a time step of $1 \mathrm{~min}$ and a distance increment of $0.05 \mathrm{~m}$ were used. The total simulation distance was $1.5 \mathrm{~m}$, and duration was $20 \mathrm{~min}$ to be comparable with the set of flume experiments.

Table 2

Input variables for the GUSED model

\begin{tabular}{lccc}
\hline Slope $(\%)$ & 1 & 3 & 5 \\
\hline Unit discharge $\left(\mathrm{m}^{2} / \mathrm{s}\right)$ & 0.00033 & 0.00067 & 0.001 \\
$\begin{array}{l}\text { Backwater depth adjacent to buffer at } \\
\text { start of experiment (mm) }\end{array}$ & 23 & 28 & 30 \\
$\begin{array}{l}\text { Input (upstream) sediment concentration } \\
\left(\mathrm{kg} / \mathrm{m}^{3}\right)\end{array}$ & 25.16 & 13.70 & 8.90 \\
\hline
\end{tabular}

\subsection{Testing of the GUSED model}

Model simulations were run for the three slopes and simulated water and deposited sediment profiles compared to measured values. The mass and particle size distribution of the deposited sediment were also compared to those predicted by the model. Coefficients of model efficiency $E c$ (Nash and Sutcliffe, 1970) were computed from the measured and simulated data as:

$$
E c=1-\frac{\sum\left(O_{i}-S_{i}\right)^{2}}{\sum\left(O_{i}-\bar{O}\right)^{2}}
$$

where $O_{i}$ and $S_{i}$ are the observed and simulated values, respectively, $\bar{O}$ is the mean of measured values. The model efficiency measures the degree of agreement between observed 
and simulated values and $E c$ values of 1 indicate a perfect fit, while increasingly negative values indicate poorer fit.

In addition, the root mean squared error (RMSE) was calculated as:

$$
R M S E=\sqrt{\frac{1}{N} \sum\left(O_{i}-S_{i}\right)^{2}}
$$

where $N$ is the number of observations. RMSE describes the magnitude of the error in simulated values in the units of the original variable, so a low RMSE indicates better fit with a zero value indicating a perfect fit. $R M S E$ is also expressed as a percentage of the mean observed value $\left(R M S E^{*} 100 / \bar{O}\right)$ to indicate the relative magnitude of errors.

\section{Results and discussion}

\subsection{Experimental results on surface flow, sediment transport and deposition}

Flows in the flume, upslope of the backwater, were subcritical, with average Froude numbers of $0.11,0.28$ and 0.53 at slopes of 1,3 and $5 \%$ respectively. An example of the recorded flow and sediment depths is presented in Fig. 3 for one of the 5\% slope replicates. The grass strip retarded flow, causing a backwater or 'ponded' area with an increased flow depth (and therefore reduced velocity) upslope of the strip. This is illustrated by the 'water profile at start' trace in Fig. 3. A maximum flow depth of $34 \mathrm{~mm}$ was recorded just prior to the grass strip and the ponded zone extended $-0.65 \mathrm{~m}$ upslope.

Upon the addition of sediment, deposition occurred in the backwater zone. This was due to the lower flow velocity in this zone, which reduced the sediment carrying capacity of the flow. Sediment was deposited in a wedge shape in the backwater zone, reaching a maximum height of $25 \mathrm{~mm}$ at $-0.07 \mathrm{~m}$ and extending $-0.8 \mathrm{~m}$ upslope of the grass strip. As deposition continued, the backwater increased in height and length, reaching a height of $40 \mathrm{~mm}$ just prior to the grass strip (Fig. 3). Similarly shaped hydrology profiles with grass strip or barrier strips have been recorded in flumes by Ghadiri et al. (2001); Dabney et al. (1995) and Meyer et al. (1995). However, the water depths we recorded were considerably smaller than those of Dabney et al. (1995) due to the lower flow rates used in our experiments but are likely to represent the subcritical flow depths in overland flow typically seen in field situations. For example, Blanco-Canqui et al. (2004) reported a ponding depth of $30 \mathrm{~mm}$ in a field study using switchgrass/fescue grass strips at $\sim 5 \%$ slope and $66 \mathrm{~mm} / \mathrm{hr}$ applied rainfall and they noted that ponding extended $0.7 \mathrm{~m}$ upslope of the barrier compared to the average values of $0.65 \mathrm{~m}$ and $0.8 \mathrm{~m}$ measured at the start and end respectively, of our experiment.

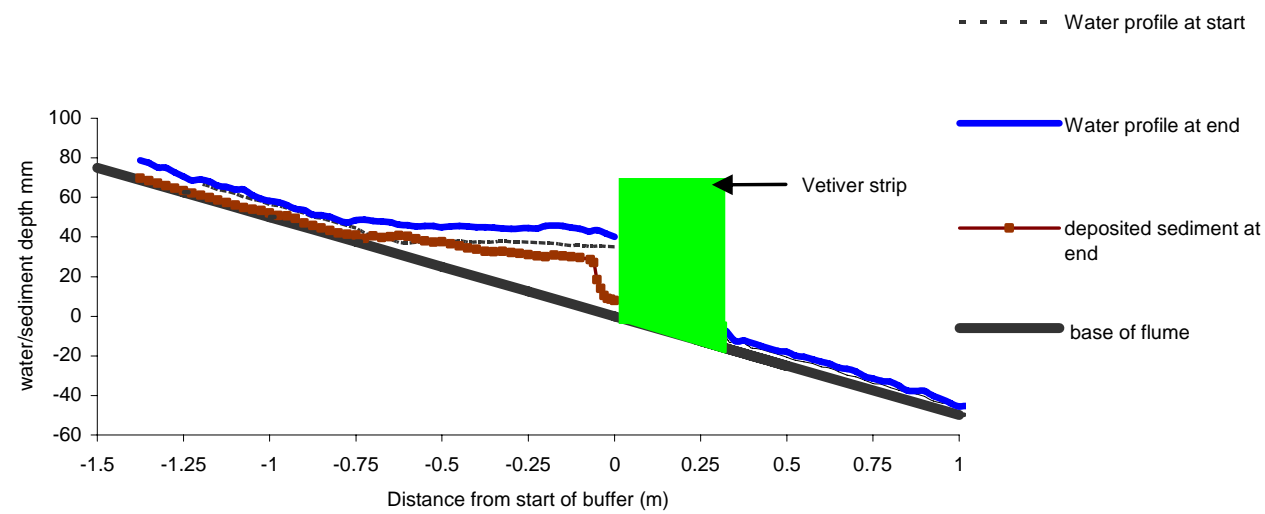

Fig.3. Measured water and sediment profiles before and after the vetiver strip at 5\% slope. Water/sediment depths and locations are reported relative to start of buffer at $0 \mathrm{~mm}$ height 
and $0 \mathrm{~m}$ distance respectively. Experiment duration was 20 minutes. Flow is from left to right.

Sediment was primarily deposited upslope of the grass strip and was generally smooth in appearance. Observation of sediment deposition within the strip was not possible due to the dense vetiver foliage. However, unless the vetiver is overtopped, it is unlikely that much sediment would be deposited within the narrow strip, even at these low subcritical flows. There is probably an increase in velocity within the strip due to channelling of flow around stems and a decreased flow depth from the entrance to the exit of the buffer (Fig. 3). Sediment deposits (apart from a few coarse grains) were also not generally observed downstream of the grass strip, except for one replicate at 5\% slope, where a thin ribbon of deposit was evident in the centre of the flume. This was due to the slight rilling developed in the upslope sediment deposit during this experiment. Flow rate therefore increased in the rill and this caused greater sediment movement through the buffer. On exiting the buffer, flow was spread across the flume, reducing the flow rate and causing deposition of the exiting sediment. Ghadiri et al. (2001) reported that coarse fractions of sediment deposited soon after exiting a nail bed, at low to moderate flows, whilst Dabney et al. (1995) observed no downstream deposition for flume experiments at $5 \%$ slope, where flow was supercritical and had a considerable vertical velocity component. Tadesse and Morgan (1996) also reported the occurrence of re-entrainment or reincision of a deposited sediment bed at slopes greater than 5\%, for run-on experiments using fescue and meadow grass strips.

Table 3 summarises the sediment deposition profiles for each slope. As slope increased, the zone of maximum deposition approached the grass strip. Simular trends were reported by Ghadiri et al. (2001). The deposit at 5\% was higher and shorter in length due to the shorter backwater, as opposed to the longer and lower deposits at 1 and $3 \%$ slopes. The volume of deposited sediment decreased with increasing slope.

Table 3 Description of sediment deposits upstream of grass strip for three slopes (standard errors
are shown in parenthesis)

\begin{tabular}{lcccc}
\hline Slope (\%) & 1 & 3 & 5 & Regression \\
\hline $\begin{array}{l}\text { Maximum height of sediment } \\
\text { deposit } \\
(\mathrm{mm})\end{array}$ & $13.3(0.3)$ & $14.5(0.4)$ & $20.7(2.3)$ & $\begin{array}{c}\text { Height }(\mathrm{mm})=4.14 \text { ln slope }+12.74 \\
\left(\mathrm{R}^{2}=0.55\right)\end{array}$ \\
$\begin{array}{l}\text { Mean location of maximum } \\
\text { height of sediment deposit } \\
\text { relative to start of grass strip } \\
(\mathrm{m})\end{array}$ & $-1.32(0.04)$ & $-0.22(0.03)$ & $-0.04(0.01)$ & $\begin{array}{c}\text { Maxpos }(\mathrm{m})=0.81 \text { ln slope }-1.29 \\
\left(\mathrm{R}^{2}=0.98\right)\end{array}$ \\
$\begin{array}{l}\text { Mean length of sediment } \\
\text { deposit } \\
(\mathrm{m})\end{array}$ & $1.28(0.04)$ & $0.95(0.03)$ & $0.65(0.05)$ & $\begin{array}{c}\text { Length }(\mathrm{m})=-0.38 \ln \text { slope }+1.30 \\
\left(\mathrm{R}^{2}=0.90\right)\end{array}$ \\
$\begin{array}{l}\text { Volume of sediment deposit } \\
\left(\mathrm{m}^{3} \times 10^{-3}\right)\end{array}$ & $3.2(0.3)$ & $2.7(0.3)$ & $2.5(0.2)$ & $\begin{array}{c}\text { Volume }\left(\mathrm{m}^{3}\right)=-0.18 \text { slope }+3.37 \\
\left(\mathrm{R}^{2}=0.71\right)\end{array}$ \\
\hline
\end{tabular}

Particle size distributions of the upslope deposited sediment were analysed according to slope and were later compared to model simulations (section 3.2). The size distribution was fairly similar to that of the inflow sediment at the most upslope end of the flume (Fig. 4). However, there was some increase in coarseness towards the grass strip with a significant increase $(p<0.05)$ in the percentage of $0.2-2.0 \mathrm{~mm}$ particles at 1 and $3 \%$ slopes, relative to the inflow. Changes in the other particle size groups were not significantly different however. If the mean weight diameter (MWD) is used as an overall indication of size of the deposited sediment, Fig. 5 shows that there is a trend of slightly increasing MWD, rather than a decreasing MWD approaching the grass strip at 1 and $3 \%$ slopes but this is not so evident at $5 \%$ slope, because 
of the increase in scatter of points. This scatter is probably due to the increased turbulence and flow transition from sub to super-critical flow at $5 \%$ slope.

Our data therefore suggests an increase in coarseness of deposited sediment towards the grass strip. However, current deposition theory (mainly derived from research on faster, supercritical flows) suggests that the coarser material should drop out of suspension furthest upslope from the grass strip, at the starting position of the backwater. This is due to its higher settling velocity and decreased rate of re-entrainment (as a result of decreased flow velocity). Dabney et al. (1995) using supercritical flow reported that the particle size and bulk density of a deposited silty soil (Dubbs sediment) increased as distance upslope from the strip increased, in agreement with the theory. Rose et al. (2003) likewise found the coarsest deposits near the initial hydraulic jump at 1.6 and $3.4 \%$ slope. A jump occurs when water passes turbulently from a region of low depth/high velocity to a region of high depth/low velocity can form only when the upstream flow is supercritical. However in the same set of experiments at $5.1 \%$ slope, Rose et al. (2003) noted finer material was deposited at the jump, with coarser material being measured nearest to the grass strip, in contradiction of the deposition theory. The trend of increased coarseness towards the grass strip at these subcritical flows has been observed even more clearly for other, coarser, soils and is the subject of further research. Coarser aggregates and sand particles were observed rolling over the surface of the bed during these and other experiments, indicating possible bedload transport. This is likely to contribute to the overall movement of sediment under these low flow conditions, in addition to the usual saltation, suspension, and deposition processes. Thus, erosion theory may need to be expanded, in order to explicitly recognise the contribution to sediment flux made by such coarser bedload sediment 


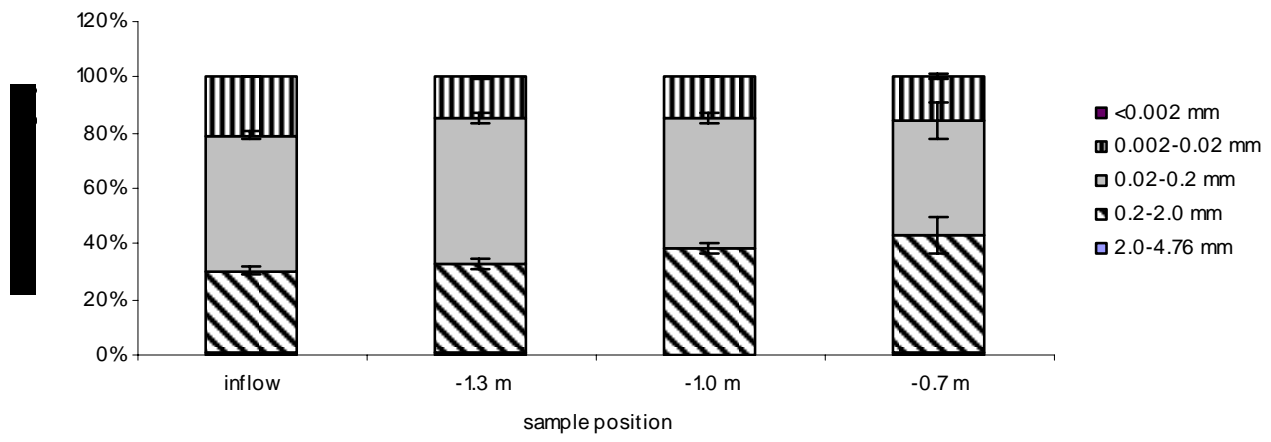

3\%slope

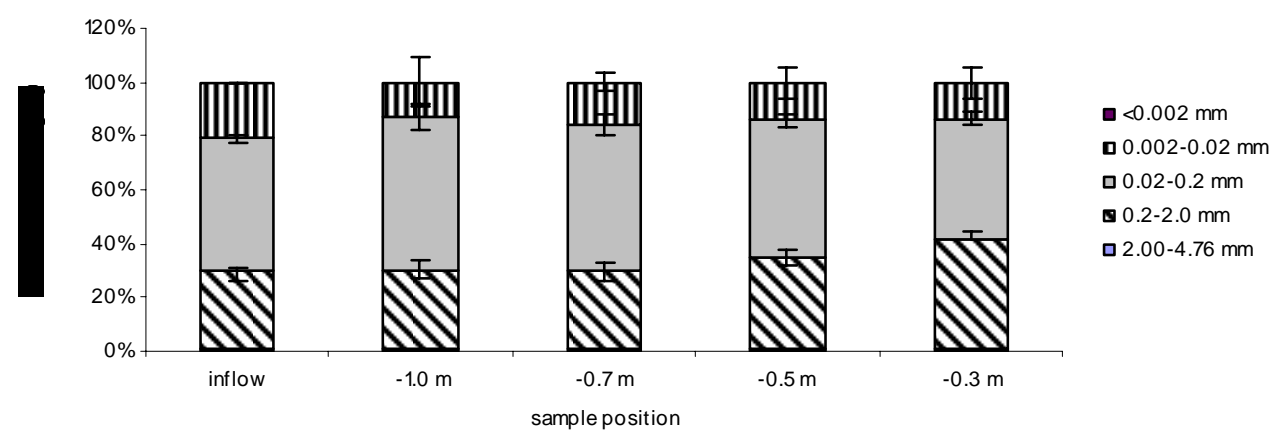

5\% slope

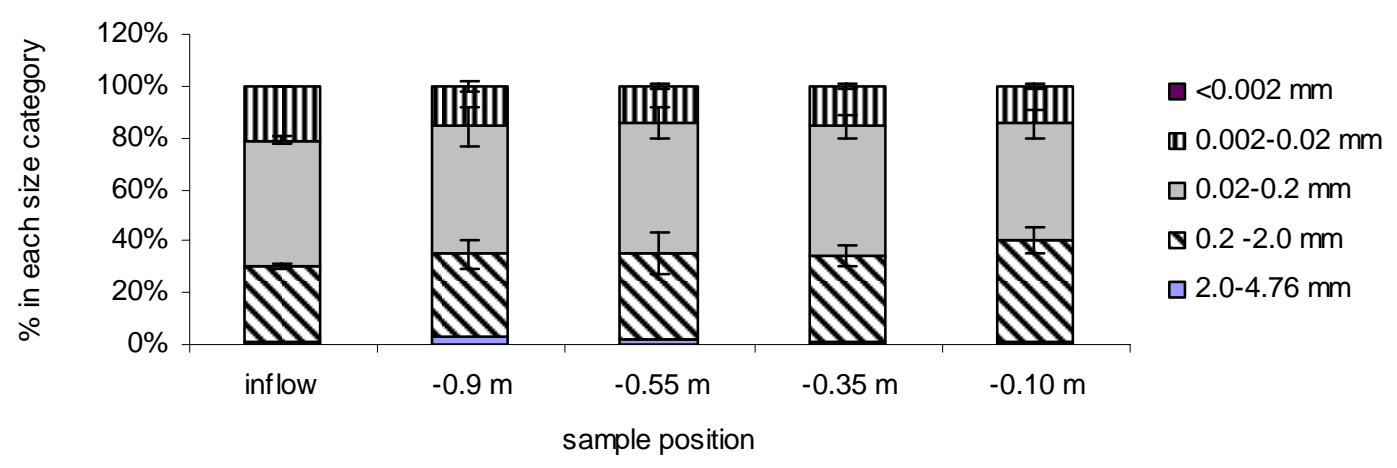


Fig.4. Size distribution of sediment deposited at different distances upstream of the buffer at 1,3 and 5 $\%$ slopes. Coarsest fractions are towards the bottom and finer fractions at the top of each column. Barred lines indicate standard error of the average values.

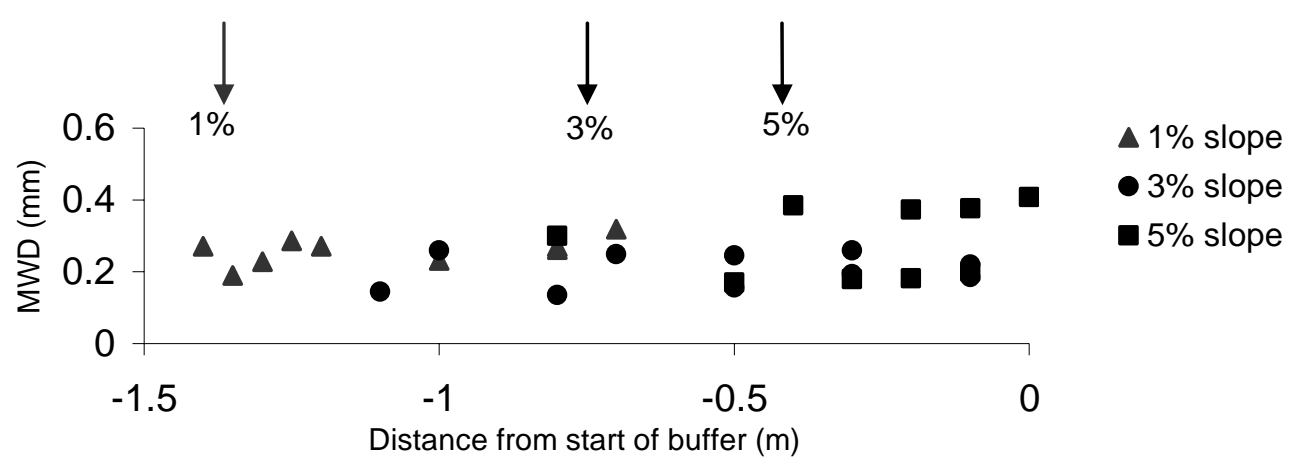

Fig.5. Mean weight diameter (MWD) of deposited sediment at different positions relative to the start of the buffer. Arrows indicate average start of backwater at each slope

One of the model inputs required to generate sediment profiles is the porosity of the deposited sediment. In order to generate the porosity, the dry and wet (saturated) bulk densities were therefore determined, giving low mean values of $0.65( \pm 0.04)$ and $1.25 \mathrm{Mg} / \mathrm{m}^{3}( \pm 0.09)$ respectively at $5 \%$ slope. Porosity of the deposited sediment was therefore conversely high, at $0.75 \pm 0.01 \mathrm{Mg} / \mathrm{m}^{3}$. The high porosity indicates open packing of aggregates within the thin net deposition layer. Dabney et al. (1995) reported higher dry bulk densities $\left(>1.15 \mathrm{Mg} / \mathrm{m}^{3}\right)$ for the loamy sediments used in their experiments, presumably due to the coarser texture of the sediment. It is also likely that the greater deposition depth $(>63 \mathrm{~mm})$ generated by the $230 \mathrm{~kg}$ of soil used in their experiments, caused settling and internal compaction within the deposits.

Sediment loads in the outflow (calculated as a percentage of the inflow concentration) are presented in Table 4. The effectiveness of the grass strip in reducing sediment load decreased with increasing slope (Table 4$)$ and there were significant differences $(p<0.01)$ in sediment reduction between slopes. This decrease in effectiveness is probably due to the decreasing backwater length, which thus allowed less length (and therefore less time) for the suspended particles to settle. Power regressions of sediment concentrations in the outflow with time are all significant at $\mathrm{p}<0.05$ (Table 4). Overall sediment loads were effectively reduced to between 5.9 to $11.6 \%$ by the grass strip, indicating that $\sim 94$ to $88 \%$ of the inflow sediment was deposited in the backwater. Trapping efficiency was therefore high under these subcritical flow rates. This efficiency may be reduced at higher, supercritical, flow rates. For comparison, Meyer et al. (1995) reported decreased trapping efficiencies of 78 to $49 \%$ for $20 \mathrm{~cm}$ vetiver strips in a flume at $5 \%$ slope, at flow rates of 0.011 to $0.043 \mathrm{~m}^{3} / \mathrm{m}$.s, which were considerably higher than those used in our study. However, subcritical flow rates are more typical for overland or sheet flow in the field particularly when there is good surface cover (Emmett, 1978; Presbitero et al., 2005) suggesting that sediment trapping for this type of flow is probably efficient. This has been confirmed in a number of field studies on grass buffer strips which show high sediment removal efficiencies at moderate slopes and flows. For example, Blanco-Canqui et al. (2004) found that narrow switchgrass hedges improved the sediment 
trapping efficiency of short fescue grass and trapped $91 \%$ of the incoming sediment at a slope of $\sim 5 \%$ and $66 \mathrm{~mm} / \mathrm{hr}$ applied rainfall.

Table 4

Mean percentage of sediment in the outflow relative to the inflow (standard errors are shown in parenthesis) and in relation to time.

\begin{tabular}{ccccl}
\hline $\begin{array}{c}\text { Slope } \\
\%\end{array}$ & $\begin{array}{c}\text { Mean \% of the inflow } \\
\text { sediment in the outflow }\end{array}$ & Regression equations & $\mathrm{R}^{2}$ & \multicolumn{1}{c}{ Significance of $\mathrm{F}$} \\
\hline 1 & $5.9(0.2)$ & $C p=3.106 \mathrm{t}^{0.2684}$ & 0.19 & $0.045^{*}$ \\
3 & $10.2(0.8)$ & $C p=4.524 \mathrm{t}^{0.4218}$ & 0.41 & $0.001^{* *}$ \\
5 & $11.6(0.5)$ & $C p=5.663 \mathrm{t}^{0.3173}$ & 0.51 & $5.09 \mathrm{E}^{-6 * * *}$ \\
\hline
\end{tabular}

Equations are derived from regression of $C p$ (outflow/inflow concentration expressed as a \%) against $\mathrm{t}$ (time in min) from start of sediment addition.

The sediment in the outflow was mostly in the 0.002 to $0.2 \mathrm{~mm}$ range, much finer than sediment in the inflow (Fig. 6). There were significant differences $(p<0.01)$ between the amount of $0.2-2.0$ and $0.02-0.2 \mathrm{~mm}$ sizes in the outflow compared to the inflow, indicating that the grass strip reduced coarse material in the flow, whilst the proportion of $0.002-0.02 \mathrm{~mm}$ (silt) size was significantly increased $(\mathrm{p}<0.01)$ in the outflow. Meyer et al. (1995) likewise reported that 90 to $100 \%$ of sediment $>0.125 \mathrm{~mm}$ from four loamy soils was deposited in their flume experiments, and outflow consisted primarily of fine sand size $(<0.125 \mathrm{~mm})$, silt and clay

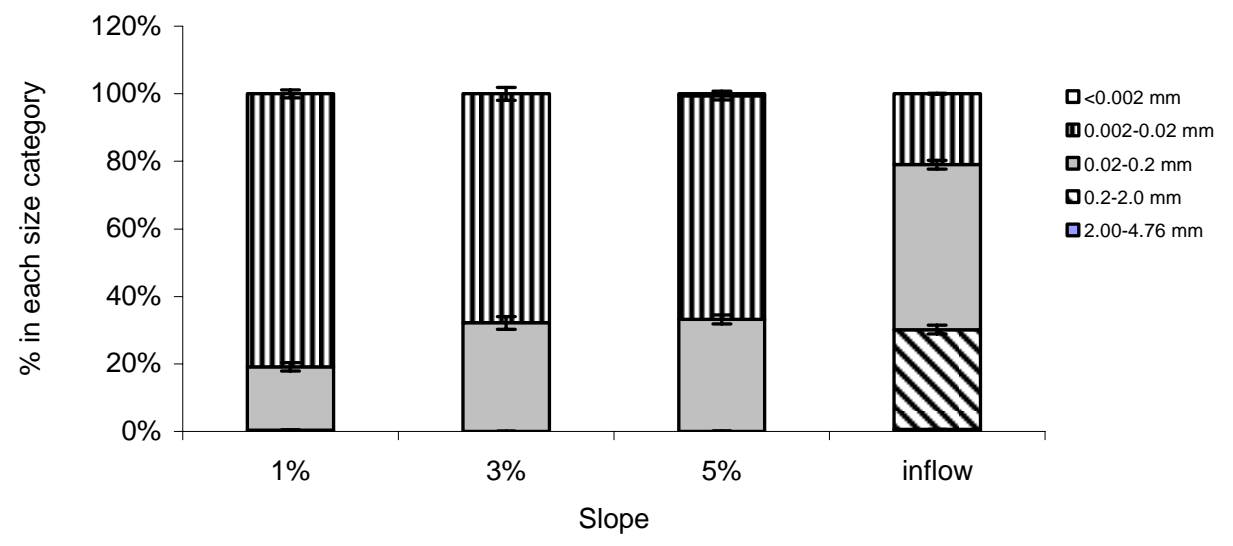

Fig. 6. Particle size of sediment in runoff at different slopes compared to inflow

As slope increased, the sediment in the outflow was coarser (Fig. 6), with a significantly increased percentage in the $0.02-0.2 \mathrm{~mm}$ size $(\mathrm{p}<0.05)$ and a significantly decreased percentage of the 0.002-0.02 mm size $(\mathrm{p}<0.05)$. Thus the soil trapping processes were less effective in removing coarser particles as slope increased. Presumably this is due to the decreased backwater zone at higher slope thus affording less settling time for particles. Despite the Vertisol being composed primarily of clay (Table 1), there were no clay-sized particles measured in the outflow. The sediment thus remained aggregated at these low flows and did not disperse to any measurable degree. The introduction of rainfall could however lead to greater breakdown of aggregates and to raindrop 'stripping' as described by Ghadiri and Rose (1993). 
The removal of coarse material from the outflow will reduce sediment and pollutant loads carried to water bodies. However transmission of fine suspended particles through grass strips has implications as fine particles often carry a disproportionately larger percentage of contaminants because of their high surface area to volume ratio (Newham et al., 2005). This transmission may be further complicated with the addition of rainfall, due to 'stripping' of aggregates. The potential enrichment of sorbed chemicals through buffers is thus a complex process requiring further study.

\subsection{Comparison of measured and simulated water and sediment profiles and size distributions}

Measured versus simulated profiles are presented for the 1 and 5\% slopes in Figs. 7 and 8, respectively and goodness of fit parameters are shown in Table 5. Simulated water profiles matched measured values fairly closely for all slopes although simulated profiles were considerably smoother than the measured data (Fig. 7). Undulations in the measured water profiles were possibly due to slight undulations in water levels which caused the dye to dissolve unevenly on the PVC strips. The mean $E c$ value for all the simulated water profiles was 0.73 , approaching the value of 1 which indicates a perfect fit, whilst the average $R M S E$ and magnitude of error were low, indicating close agreement between simulated and measured data. The largest difference $(\Delta i)$ between measured and simulated water elevation data (Table 5) for all simulations was found to be $6.4 \mathrm{~mm}$ (data corrected for slope relative to the start of the buffer). This represented the difference between a measured $(66.4 \mathrm{~mm})$ and a simulated $(60 \mathrm{~mm})$ water elevation in one of the $5 \%$ slope experiments. When this $6.4 \mathrm{~mm}$ is computed as a percentage of the measured $60 \mathrm{~mm}$ value, the difference between measured and simulated data is only $10 \%$ of the measured data indicating an acceptable scale of difference. This difference is lower than that reported by Deletic and Fletcher (2005) for agreement between measured flow depths (in field experiments on grass filters) and those predicted by the model TRAVA, which was within $20 \%$ of measured depths.
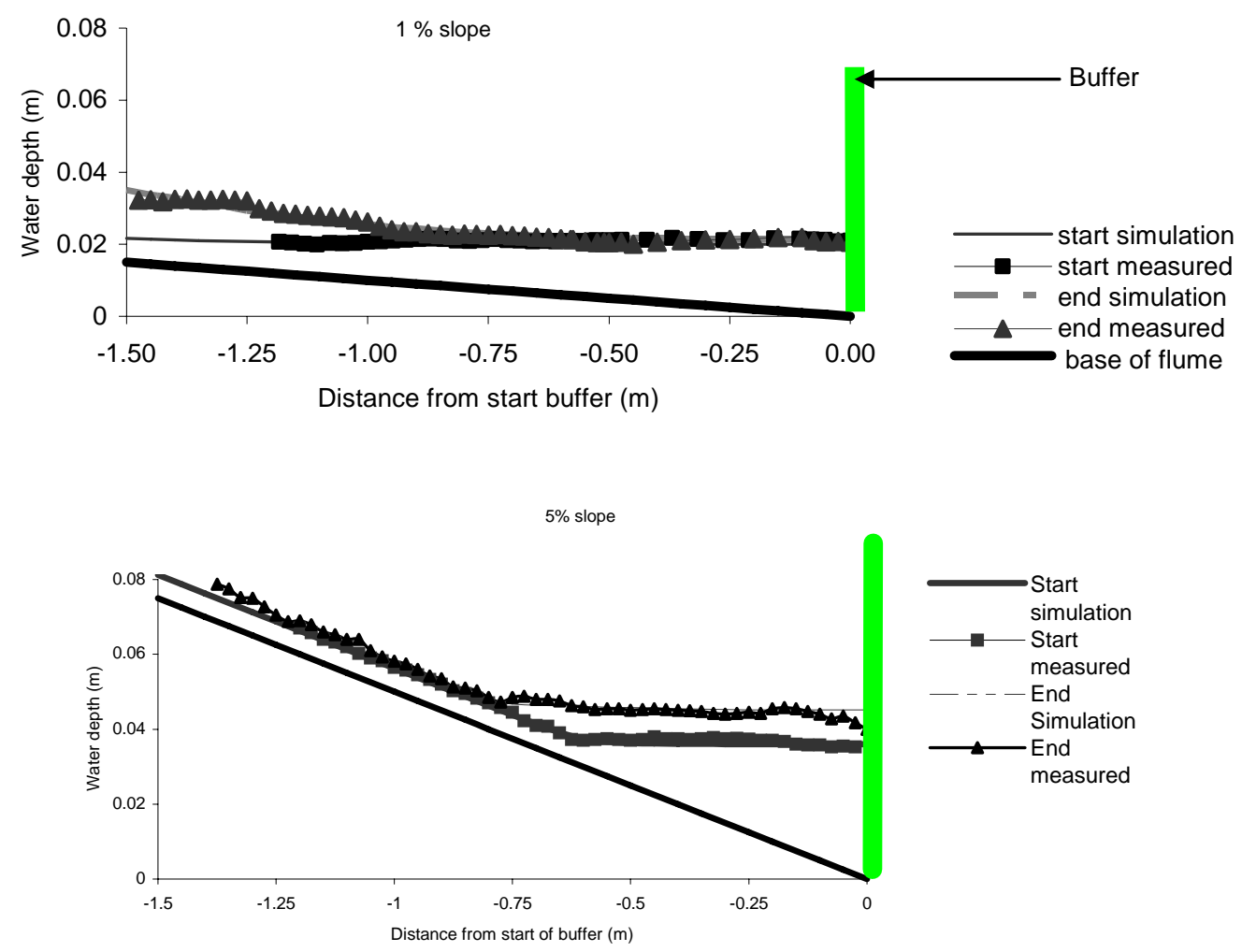

Fig. 7. Measured versus simulated water profiles upstream of the buffer at the start and end of the experiment for two slopes. 
$1 \%$ slope
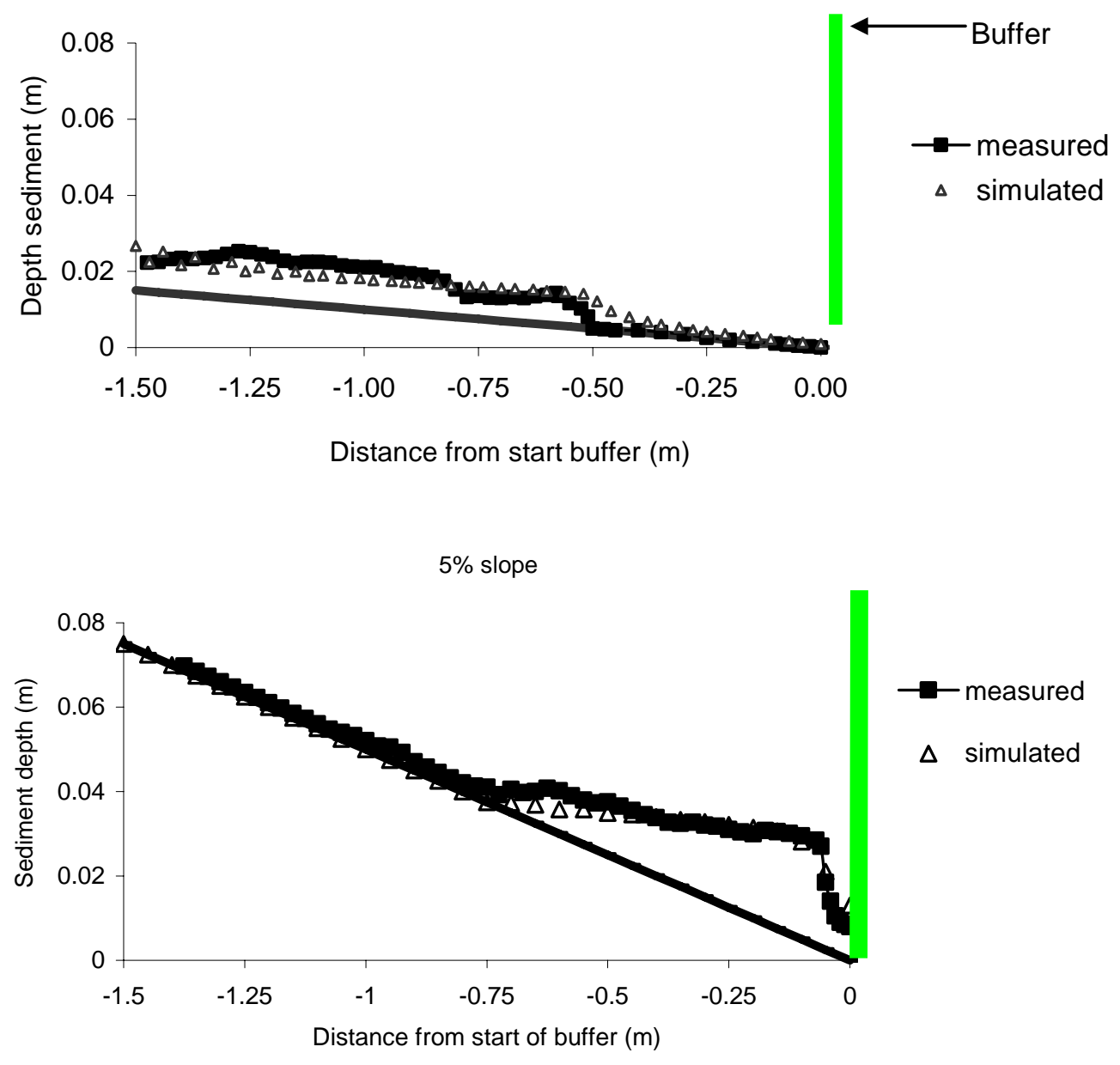

Fig. 8. Measured versus simulated deposited sediment profiles upstream of the buffer for two slopes

The simulated sediment profiles were very similar in overall shape to the measured data but generally indicated some deposition a little closer to the grass strip than was measured at $1 \%$ slope (Fig. 8). The mean $E c$ value for the sediment profile again approached 1 (Table 5) but the RMSE and magnitude of errors were larger, indicating greater differences between observed and simulated data. The maximum difference $(\Delta i)$ between measured and simulated sediment heights was $8.7 \mathrm{~mm}$ (Table 5) at 5\% slope for a measured height of $40 \mathrm{~mm}$, giving a maximum $22 \%$ difference. The simulated sediment profiles are therefore not as good a fit as the water profiles but are within an acceptable range.

The total mass of sediment deposited from the flume experiments within the area of $1.5 \mathrm{~m} \mathrm{x}$ $0.3 \mathrm{~m}$ upslope of the grass strip ( $\mathrm{kg}$ sediment per $0.45 \mathrm{~m}^{2}$ area) was compared to the simulated data, obtained from the sediment profiles at each slope. The fit was not as good (Table 5) with the Ec value drifting further below the ideal of 1 and a higher RMSE. The maximum difference between the measured and simulated total sediment deposits was $1.021 \mathrm{~kg}$ per $0.45 \mathrm{~m}^{2}$ (Table 5), for a simulation at $5 \%$ slope, equal to $31 \%$ of the measured value of $3.27 \mathrm{~kg}$ per $0.45 \mathrm{~m}^{2}$. However, there was less than $20 \%$ difference for most simulations. Thus although the simulation is not ideal, it does give a 'ball park' indication of total deposition by the grass strip. 
In order to compare the measured and simulated particle sizes of deposited sediment, measured data were taken from samples closest to the buffer (i.e. $x=0 \mathrm{~m}$ ). Fig. 9 presents these comparisons for the three slopes. The simulated particle sizes typically show larger fractions in the $0.02-0.2 \mathrm{~mm}$ size range and smaller fractions in the $0.002-0.02 \mathrm{~mm}$ size ranges than were measured. The $E c$ value for the simulations is close to 1 (Table 5), but the relative magnitude of error is high due to large differences between the measured and observed data in two of the size classes. Accurate prediction of the particle size of the deposited sediment, and thus by difference the particle size of sediment in the buffer and in the outflow, would be most useful for research on pollutant/nutrient transport, as pollutants/nutrients are often preferentially adsorbed to finer sediment fractions. In order to quantify the particle size in the outflow at the start and exit of the buffer, a technique to sample this outflow is being developed for future experiments. This will be used to test the model output and to improve the model predictions.

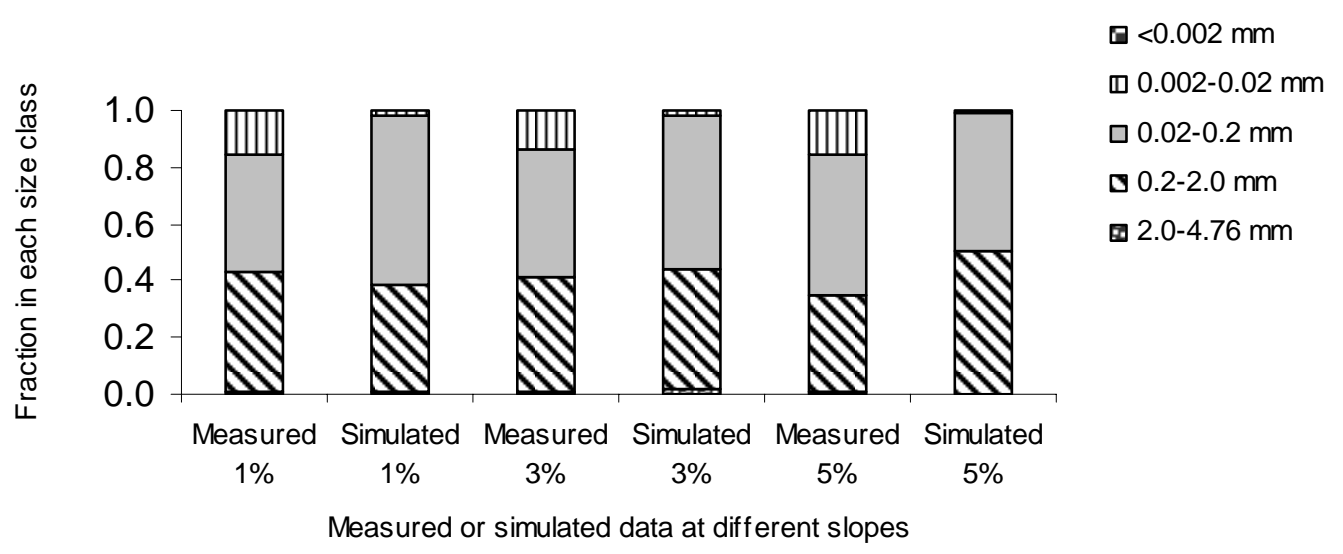

Fig.9. Measured versus simulated particle size of deposited sediment

Table 5

Goodness of fit parameters assessed from a comparison of measured versus simulated water and sediment profiles.

\begin{tabular}{|c|c|c|c|c|}
\hline Type of simulation & $E c$ & $R M S E$ & $\begin{array}{l}\text { Relative magnitude of } \\
\text { error }(\%)\end{array}$ & $\begin{array}{c}\text { Maximum } \\
\qquad i\end{array}$ \\
\hline Water elevation in flume (mm) & 0.73 & 0.0012 & 3.47 & 6.4 \\
\hline $\begin{array}{l}\text { Sediment elevation in flume } \\
(\mathrm{mm})\end{array}$ & 0.86 & 0.2033 & 12.94 & 8.7 \\
\hline $\begin{array}{l}\text { Total sediment deposited } \\
\text { upstream of grass strip } \\
\left(\text { kg per } 0.45 \mathrm{~m}^{2}\right)\end{array}$ & 0.32 & 0.6157 & 21.98 & 1.021 \\
\hline $\begin{array}{l}\text { Particle size of deposited } \\
\text { sediment (Fractions in each of } 5 \\
\text { size classes) }\end{array}$ & 0.86 & 0.924 & 46.22 & 0.150 \\
\hline
\end{tabular}

$\Delta i=($ measured - simulated value $)$

Simulations were run at each of the three slopes (1, 3 and 5\%) and values were averaged from the 3 simulations. Parameters are defined in section 2.4 


\section{Utilization of the GUSED model for sediment retention predictions 4.1 Predicting backwater depths}

The GUSED model requires input of the initial maximum backwater depth for prediction of sediment removal by buffer strips. However, of all the information required to run the model, this is probably the least readily available, as it is not routinely measured especially in field situations. As a first step to solving this problem, the initial depth and extent of the backwaters measured at the 3 slopes are shown in Fig. 10. It can be seen that as slope increases, the backwater increases in depth and decreases in length. The decreasing length causes the sediment to be deposited closer to the grass strip, as the zone of reduced velocity moves closer to the grass strip. Fig. 10 indicates that the backwater length would approach zero at $\sim 7 \%$ slope. This is simular to that found by Ghadiri et al. (2001) where the backwater moved into a barrier strip, (hence $<0 \mathrm{~m}$ ) between 6.6 and $8.8 \%$ slope. Ghadiri et al. (2001) also noted that the maximum backwater depths were about 2 to 3 times the height of the initial flow before the start of the backwater. The maximum backwater depths measured in our experiments prior to sediment addition ranged from 21 to $34 \mathrm{~mm}$ and were 2 to 5 times the initial flow depth, due to the increased flow resistance offered by the vetiver grass in contrast to the nail beds tested by Ghadiri et al. (2001).

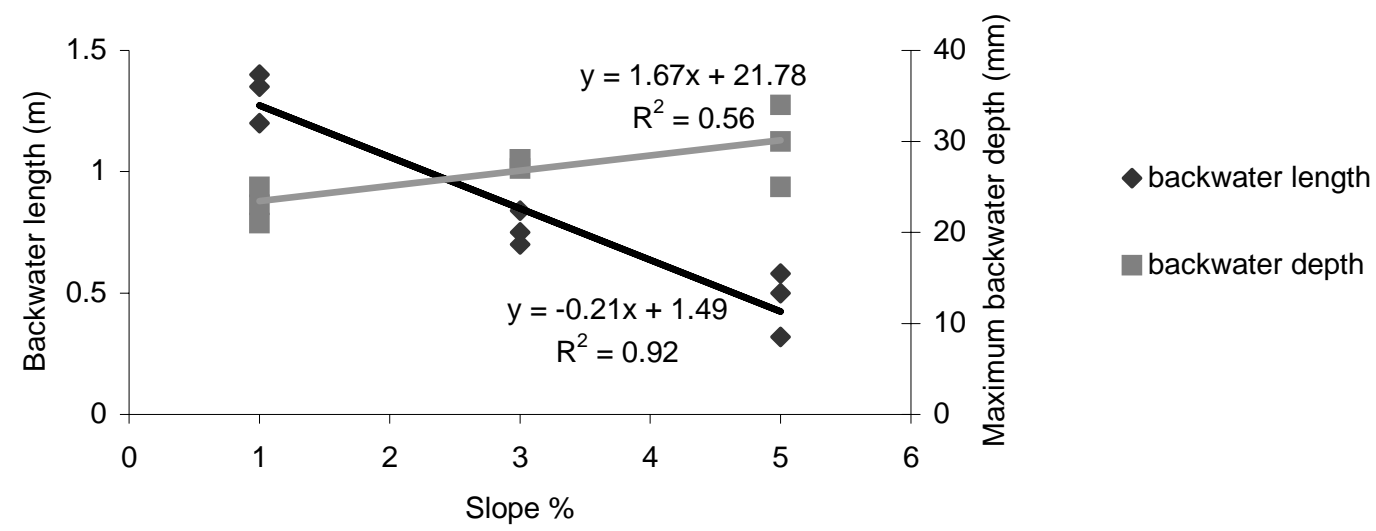

Fig. 10. Variation of initial backwater length and maximum depth with slope, in the absence of sediment addition. Maximum depth was recorded adjacent to the start of the buffer.

If the slopes in Fig. 10 are replaced by the comparable flow rates of $0.00033,0.00067$ and $0.001 \mathrm{~m}^{3} / \mathrm{m}$.s used at 1,3 and $5 \%$ slopes respectively, the maximum depth of the backwater can be predicted from flow rate by the equation:

$D \max =9930 q+20$

where $D$ max is the maximum backwater depth $(\mathrm{mm})$ and $q$ is the unit flow rate $\left(\mathrm{m}^{3} / \mathrm{m} . \mathrm{s}\right)$.

Using this equation to predict backwater heights at the high flow rates $(0.02183$ to 0.04367 $\mathrm{m}^{3} / \mathrm{m}$.s) used by Dabney et al. (1995) for a $20 \mathrm{~cm}$ vetiver hedge in the same size flume at $5 \%$ slope, values of 237 to $454 \mathrm{~mm}$ are computed in comparison to their measured values of 274 to $390 \mathrm{~mm}$. Additionally, if the equation is used for the data of Dalton (1997) from vetiver hedges at $0.25 \%$ slope, (flow rates 0.02 and $0.04 \mathrm{~m}^{3} / \mathrm{m} . \mathrm{s}$ ), predicted heights of 219 and 417 $\mathrm{mm}$ are similar to the range of values found by Dalton $(230-350 \mathrm{~mm}$ and $320-460 \mathrm{~mm})$,. This agreement between predicted and calculated backwater depths indicate that as a first approximation, the equation can be used for these and other literature studies at similar slopes. 
Further work is planned to assess backwater heights for field situations. Once backwater depths can be accurately predicted for a given subcritical flow, slope and type of buffer (all routinely measured for many catchments) then input of the sediment characteristics into the GUSED model will generate the amount of deposition occurring upslope of the buffer, as well the amount and particle size of sediment passing into the buffer. This should provide a valuable tool for assessing sediment and associated pollutant loads being delivered from different landscapes into water bodies.

\subsection{Prediction of sediment trapping}

As discussed in 3.2, the GUSED model can be used to predict Vertisol sediment retention, usually within $20 \%$ of the measured values. It can thus be used to generate approximate sediment trapping efficiencies for different flow, slope and inflow conditions for this soil. A few examples of these simulations are illustrated in Fig. 11. Trapping efficiency is calculated as $\left[\left(C_{i n}-C_{\text {out }}\right) / C_{\text {in }}\right]$ where $C_{\text {in }}$ is the inflow sediment concentration $\left(\mathrm{kg} / \mathrm{m}^{3}\right)$ and $C_{\text {out }}$ is the outflow sediment concentration at the start of the buffer strip, also in $\mathrm{kg} / \mathrm{m}^{3}$. This kind of data could be used to refine the design of conservation systems utilizing grass strips in the field, such as those described in Lovett and Price (1999). As expected the trapping efficiency is greater at 1\% slope compared to 5\% slope at comparable flows, due to the longer backwater and thus settling distance at $1 \%$ slope. Thus the spacing of vetiver hedges needs to be closer at higher slopes and flows to trap sediment effectively. Trapping efficiency likewise decreases with increasing flow at each slope due the increased sediment transport capacity of the flow. As sediment concentration in the inflow decreases from $25 \mathrm{~kg} / \mathrm{m}^{3}$ to $5 \mathrm{~kg} / \mathrm{m}^{3}$ (Fig. 11), the trapping efficiency is lower for the lower concentration. This is due to the greater total deposition at the higher concentration which gives a greater relative increase in the depth and length of the backwater, thus increasing the time for settling. For example at $0.01 \mathrm{~m}^{3} / \mathrm{m}$.s flow and $5 \%$ slope, the backwater length for the $25 \mathrm{~kg} / \mathrm{m}^{3}$ concentration inflow increase from $1.7 \mathrm{~m}$ at the start to $4.0 \mathrm{~m}$ after 20 minutes, with the sediment deposit extending $\sim 3 \mathrm{~m}$ upslope of the buffer and having a maximum depth of $40 \mathrm{~mm}$. In contrast the backwater length for the $5 \mathrm{~kg} / \mathrm{m}^{3}$ inflow only changes from 1.7 to $2.5 \mathrm{~m}$ with a sediment deposit of $1.5 \mathrm{~m}$ length and maximum height $10 \mathrm{~mm}$, as less soil is deposited in the same time period. We noted this same trend in our experiments and where there is considerable sediment deposit, the sediment itself can produce a secondary barrier upslope of the buffer, thus inducing a higher and longer backwater. Further flume experiments with different sediment types are underway and data from these will be used to further test the model. It is also envisaged that the model will be tested using field data.

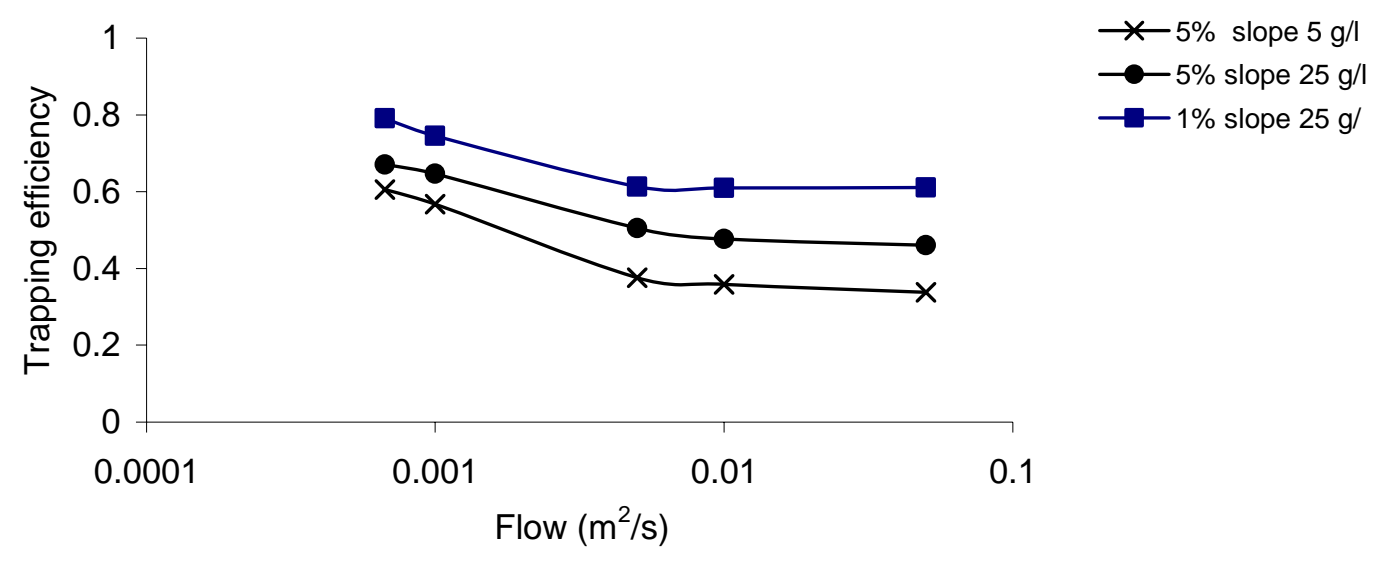

Fig.11. Simulated trapping efficiency of a $30 \mathrm{~cm}$ vetiver strip for Vertisol sediment at different flow rates, slopes and input concentrations. Note: Sediment is introduced upstream of start of backwater, Manning $\mathrm{n}=0.05$, backwater depths are calculated from Eq.6. , $F=0.1$. 


\section{Conclusions}

The reported experiments show that at low slopes and subcritical flow rates $\leq 0.001 \mathrm{~m}^{3} / \mathrm{m}$.s, a vetiver grass strip retarded flow producing a backwater. This caused settling of the inflow sediment, with up to $94 \%$ being deposited upslope of the grass strip. Backwaters were higher and shorter as slope increased. The deposited sediment was coarser towards the grass strip in contrast to current deposition theory which predicts that the coarsest deposits should be furthest upslope from the grass strip. Further study on bedload transport and the rolling of coarse particles is underway to explain this anomaly. The proportion of sediment, as well the proportion of coarse material in the outflow, increased with increasing slope. The vetiver strip was therefore least effective at 5\% slope. Buffer systems incorporating these strips should thus be designed more conservatively for steeply sloping land.

A newly developed erosion and deposition model (GUSED) was introduced, which couples the changing hydraulics with sediment addition, therefore allowing changes in sediment retention by buffers to be predicted with time. The inputs for the model are readily obtainable from many field and laboratory studies, except for the backwater height adjacent to the upslope edge of the buffer. However, an equation developed from our data can be used as a first approximation to predict this backwater height for vetiver hedges, for known flow rates. The model was used to simulate water and sediment profiles upslope of the vetiver strip and was tested by comparing the simulated to measured data. Water profiles, before and after sediment addition, were well simulated with $E c$ values approaching 1. There was a reasonable fit for the sediment profiles with differences between simulated and measured data being less than $22 \%$ of the measured values. The mass of sediment deposited upslope of the buffer was predicted within $31 \%$ of measured values. Predicted particle sizes of deposited sediment had less coarse and fine fractions and more medium-size fractions than those measured in the flume. Overall the model appears to provide a very useful start for estimating sediment retention by grass strips but further testing using both laboratory and field data is desirable.

\section{Acknowledgements}

The buffer strip work is funded by an ARC Discovery Project Grant (DP 0451654) The authors wish to thank Joe McMahon and Hapsara Mahardhika for assistance with the flume experiments, Mr Aubrey Chandica for help with the digitisation and Dr Paul Truong for sourcing and providing information on vetiver.

\section{References}

Australian Standards, 1995. AS 12898.3.6.2-1995. Method 3.6.2 Soil classification testsdetermination of the particle size distribution of a soil - analysis by sieving in combination with hydrometer analysis (subsidiary method). Government of Australia.

Blanco-Canqui, H., Gantzer, C.J., Anderson, S.H., Alberts, E.E., Thompson, A.L., 2004. Grass barriers and vegetative filter strip effectiveness in reducing outflow, sediment, nitrogen and phosphorus loss. Soil Science Society of America Journal. 68, 1670-1678.

Cash, J.R., Karp, A.H., 1990. A variable order Runge-Kutta method for initial value problems with rapidly varying right hand sides. ACM Transactions on Mathematical Software 16, 201-222.

Cheng, N.S., 1997. Simplified settling velocity formula for sediment particles. Journal of Hydraulic Engineering, American Society of Civil Engineers 123, 149-152.

Chow, V.T., 1959. Open channel hydraulics. McGraw Hill New York. 680 pp.

Dabney, S.M., 2003. Erosion Control, Vegetative. Encyclopaedia of Water Science. Marcel Dekker, Madison Ave, New York, USA.

Dabney, S.M., Meyer, L.D., Harmon, W.C, Alonso, C.V., Foster, G.R., 1995. Depositional patterns of sediment trapped by grass hedges. Transactions of the American Society of Agricultural Engineers 38, 1719-1729. 
Dalton, P.A., 1997. Application of vetiver grass hedges to erosion control on the cropped flood plain of the Darling Downs. Master of Engineering Thesis, Faculty of Engineering and Surveying, University of Southern Queensland, Australia.

Deletic, A., 2001. Modelling of water and sediment transport over grassed areas. Journal of Hydrology 248, 168-182

Deletic, A., 2005. Sediment behaviour in runoff over grassed surfaces. Journal of Hydrology 301, 108-122.

Deletic, A, and Fletcher, T.D., 2005 Performance of grass filters used for stormwater treatment - a field and modelling study. Journal of Hydrology 301, 1-15.

Dillaha, T.A., Inamdar, S.P. 1996. Buffer zones as sediment traps or sources. In: Haycock, N. Burt, T., Goulding, K., Pinay, G. (Eds.). Buffer Zones: Their Processes and Potential in Water Protection. Quest Environmental, Harpenden, Hertfordshire, U.K. pp. 33-42.

Dillaha, T.A., Reneau, R.B., Mostaghimi, S., Lee,D., 1989. Vegetative filter strips for agricultural nonpoint source pollution control. Transactions of the American Society of Agricultural Engineers 32 (2), 513-519.

Emmett, W.W., 1978. Overland flow. Chapter 5, In: Kirkby, M.J. (Ed.) Hillslope hydrology. Wiley, New York, pp.145-176.

FAO, 1998. World Reference Base for Soil Resources. World Soil Resources Report 84. FAO Rome $88 \mathrm{pp}$.

Flanagan, D.C., Nearing, M.A., 2000. Sediment particle sorting on hillslope profiles in the WEPP Model. Transactions of the American Society of Agricultural Engineers 43, 573-583.

Freebairn, D.M., Wockner, G.H., 1986. A study of soil erosion of the Eastern Darling Downs, Queensland. I. Effects of surface conditions on soil movement within contour bay catchments. Australian Journal of Soil Research 24, 135-158.

Ghadiri, H., Rose, C.W, 1993. Water erosion processes and enrichment of sorbed pesticides. Part 2. Enrichment under rainfall dominated erosion processes. Journal of Environmental Management 37, 37-50.

Ghadiri, H., Rose, C.W., Hogarth, W.L., 2001. The influence of grass and porous barrier strips on runoff hydrology and sediment transport. Transactions of the American Society of Agricultural Engineers 44, 259-268.

Isbell, R.F., 1996. The Australian Soil Classification. CSIRO Publishing. Melbourne, Australia.

Loch, R.J., Rosewell, C.J. 1992. Laboratory methods for measurement of soil erodibilities (K factors) for the Universal Soil Loss Equation. Australian Journal of Soil Research 30, 233-248.

Lovett, S., and Price, P., 1999. Riparian Land Management Technical Guidelines. Land and Water Resources Research and Development Corporation (LWRRDC) Canberra.

McKergow, L.A., Prosser, I.P., Grayson, R.B., Heiner, D., 2004a. Performance of grass and rainforest riparian buffers in the wet tropics, Far North Queensland. 2. Water quality. Australian Journal of Soil Research 42, 485-499.

McKergow, L.A., Prosser, I.P., Grayson, R.B., Heiner, D., 2004b. Performance of grass and rainforest riparian buffers in the wet tropics, Far North Queensland. 1. Riparian Hydrology. Australian Journal of Soil Research 42, 473-484.

Metcalfe, O., Truong, P., Smith, R., 2003. Hydraulic characteristics of vetiver hedges in deep flows. Proceedings of the Third Conference on Vetiver, Guangzhou, China, October 2003.

Meyer, L.M., Dabney, S.M., Harmon, W.C., 1995. Sediment trapping effectiveness of stiff grass hedges. Transactions of the American Society of Agricultural Engineers 38, 809-815.

Munoz-Carpena, R., Parsons, J.E., Gilliam, J.W., 1999. Modelling hydrology and sediment transport in vegetative filter strips. Journal of Hydrology 214, 111-129.

Nash, J.E., Sutcliffe, J.V., 1970. River flow through conceptual models, part 1 - a discussion of principles. Journal of Hydrology 10, 282-290. 
Newham, L.T.H., Rutherford, J.C., Croke, B.F.W., 2005. A conceptual model of particulate trapping in riparian buffers. CSIRO Land and Water Technical Report 21/05. CSIRO Land and Water Canberra, Australia.

Presbitero, A.L., Rose, C.W., Yu, B., Ciesiolka, C.A.A., Coughlan, K.J. Fentie, B., 2005. Investigation of soil erosion from bare steep slopes of the humid tropic Philippines. Earth Interactions 9, 005.

Press, W.H., Teukpolsky, S.A., Vetterling, W.T., Flannery, B.P., 1992. Numerical Recipes in Fortran, Cambridge University Press, Cambridge, pp. 963.

Probert, M.E., Fergus, I.F., McGarry, D., Thompson, C.H., Russell, J.S. 1987. The Properties and Management of Vertisols. CABI, Wallingford, .U.K. 36 pp.

Rayment, G.E., Higginson, F.R., 1992. Australian laboratory handbook of soil and water chemical methods. Australian Soil and Land Survey Handbook. Series 3. 330 pp.

Rose, C.W., Yu, B., Hogarth, W.L., Okom, A.E.A., Ghadiri, H., 2003. Sediment deposition from flow at low gradients into a buffer strip - a critical test of re-entrainment theory. Journal of Hydrology 280, 33-51.

Tadesse, L.D., Morgan, R.P.C., 1996. Contour grass strips: a laboratory simulation of their role in erosion control using live greases. Soil Technology 9, 834-89.

Tollner, E.W., Barfield,B.J., Vachiraskornwatana,C., Haan,C.T., 1977. Sediment deposition patterns in simulated grass filters. Transactions of the American Society of Agricultural Engineers 20, 939-942.

Truong, P.N.V., 1999. Vetiver grass technology for flood and stream bank erosion control. Proceedings of the International Vetiver Workshop Nanchang, China, October 1999.

Van Bavel, C.H.M., 1950. Mean weight diameter of soil aggregates as a statistical index of aggregation. Soil Science Society of America Proceedings 14, 20-23. 